\title{
Capital Adequacy and Systemic Risk of Banks in India
}

\author{
Mihir Dash \\ Head of Department, Quantitative Methods \& Economics \\ School of Business, Alliance University \\ Chikkahagade Cross, Anekal, Bangalore, India-562106 \\ Tel: 91-99-518-2465Ｅ-mail: mihirda@rediffmail.com
}

Received: March 1, $2020 \quad$ Accepted: April 1, $2020 \quad$ Published: June 1, 2020

doi:10.5296/ajfa.v12i1.16698 URL: https://doi.org/10.5296/ajfa.v12i1.16698

\begin{abstract}
This study examines the role of capital adequacy in systemic risk for banks in India. The moderator variables considered for the study include bank size, non-performing assets, leverage, deposits, loans \& advances, and investments. A fixed-effects panel regression model was applied, with bank fixed effects and year fixed effects.

The study contributes to the literature by proposing the concept of minimum level of capital adequacy for neutral systemic risk, which is the level of capital adequacy for which the systemic risk is non-positive. The results of the study indicate that bank size, non-performing assets, leverage, and loans \& advances have a significant impact on the minimum capital adequacy for neutral systemic risk. Further, the results of the study suggest that the role of capital adequacy in systemic impact was different for public sector and private sector banks.

The study suggests that, instead of setting a fixed capital adequacy level for all banks, the model can be used to set capital adequacy targets for individual banks with estimates or projections of the bank's characteristics. This can be used in conjunction with the Basel III framework in order to rationalise capital adequacy targets.
\end{abstract}

Keywords: systemic risk, capital adequacy, neutral systemic risk, public sector banks, private sector banks. 


\section{Introduction}

Systemic risk is defined as the impact that the failure of a bank or financial institution would have on the entire financial system and/or economy, through its network of interlinked financial intermediaries. The failure of an institution leads to financial stress on institutions that have lent money to it, which in turn may lead to failure of some of these institutions. This leads to a kind of domino or ripple effect, and spreads across the entire financial system.

The recent experience of the global financial crisis of 2008-09 and the subsequent Euro-zone crises of 2010-11 has demonstrated the importance of measuring the level of systemic risk associated with different financial institutions and understanding the factors contributing to systemic risk. The collapse of some of the most prominent banks in the world, including the Lehman Brothers and Washington Mutual Bank, along with several near-failures which had to be bailed out of crisis by the U.S. government, highlighted the significance of understanding, measuring, and monitoring systemic risk.

Many theories suggest that large and complex banks contribute to systemic risk. A possible source of the systemic importance of large, inter-connected banks is moral hazard; as regulators are reluctant to close or unwind large and complex banks, this leads banks to take on excessive risks in the expectation of government bailouts (e.g. Farhi and Tirole, 2012). Another source is that of agency effects, i.e. poor governance of large and complex banks may lead to bank managers engaging in non-traditional risky activities (e.g. trading) and tend to be financed more through short-term debt, making them more vulnerable to liquidity shocks and market failures (e.g. Laeven and Levine, 2007; Boot and Ratnovski, 2012).

Capital adequacy has been recognised by the Basel Committee of the Bank for International Settlements as an effective tool for controlling credit risk. The underlying principle was that prudential policies can control the risk exposure of the financial industry by ensuring that individual banks are managed properly. Regulation of capital adequacy was expected to decrease the probability of a bank failing and decrease the bank's losses given default (Diamond and Rajan, 2010).

The Basel III norms form a comprehensive set of reform measures, to strengthen the regulation, supervision and risk management of the banking sector. They aim to improve the banking sector's ability to absorb shocks arising from financial and economic stress, to improve risk management and governance, and to strengthen banks' transparency and disclosures. They operate at the micro-prudential level, to help raise the resilience of individual banks in periods of stress, and at the macro-prudential level, to counter systemic risks in the banking sector as well as the pro-cyclical amplification of these risks over time. The Basel III norms (post-2015) include capital requirements, including a minimum common equity tier I ratio of $4.5 \%$, a minimum tier I capital ratio of $6 \%$, a mandatory "capital conservation buffer" of $2.5 \%$, and a "discretionary counter-cyclic buffer" of $2.5 \%$ during periods of high credit growth; minimum leverage ratio of $3 \%$; and a liquidity coverage ratio in excess of $100 \%$. 
The Indian banking system, which was initially hailed to be unaffected by the crises, was affected indirectly, mainly on account of growing trade and financial integration with the global economy. Though Indian banks were not pushed to the point of insolvency, monitoring of systemic risk has become important in the dynamic banking environment in India in order to avoid potential system failure. This study examines the role of capital adequacy in controlling systemic risk for Indian banks.

The Indian banking industry has two important segments, public sector banks and private sector banks. Public sector banks are owned and controlled by the government, and are subjected to political interference and constraints. Many studies have argued that private sector banks outperform public sector banks due to professional, efficient management, and better customer focus and service, particularly in terms of Management Soundness and Earnings and Profitability (Dash and Das, 2013; Dash et al, 2015). In view of this, the role of capital adequacy in controlling systemic risk would be expected to differ between public sector and private sector banks.

\section{Literature Review}

There are many definitions of systemic risk advocated in the literature, and many more approaches proposed for their measurement. Adrian and Brunnermeier (2008) was one of the first studies to suggest a measure for systemic risk, viz. the conditional value-at-risk (CoVaR), which focuses on the tail distribution. They were able to identify the contribution of each bank to systemic risk using this measure. Acharya et al (2010a, 2010b) proposed the concept of systemic expected shortfall (SES), i.e. the amount by which a bank is undercapitalised in a systemic event in which the entire financial system is undercapitalised, to measure systemic risk. Acharya and Steffan (2012) extended the framework by introducing the concepts of marginal expected shortfall (MES), which measures the performance of a bank when the market return as a whole experiences its worst $5 \%$ trading days within a year, and the bank's market leverage ratio, the market value of assets divided by the market value of equity. Brownlees and Engle (2012, 2017) and Acharya et al (2012) suggested the SRISK index, which estimates the expected capital shortage of a bank during on a substantial market meltdown, as a measure for systemic risk. Moore and Zhou (2014) proposed the expected system loss (ESL), viz. the expected loss to the financial system as a whole given that a particular bank fails, which they estimated using multivariate extreme value theory, as a measure of systemic importance of the bank. Hattori et al (2014) pointed out that systemic risk measures are essentially a form of scenario analysis, as they analyse the impact of certain types of assumed trigger events on the financial system, based on past patterns of failure; however, this may not be an indicator for robustness against future, unprecedented modes of failure. Also, they argued that most market-based estimates of systemic risk may overestimate the importance of short-term changes. They suggested combining different systemic risk measures together with macro-stress testing scenarios, providing a wider range of potential sources of failure. van Oordt and Zhou (2015) analysed bank systemic risk into two dimensions, the level of bank tail risk and the linkage between the level of bank tail risk and severe financial shocks to the system. 
Several studies have analysed the determinants of systemic risk and systemic importance of banks. Moore and Zhou (2014) found that size and non-traditional banking activities were the significant determinants of systemic importance of US banks in the period 2000-10; in particular, they found that banks above a certain size have equal systemic importance. Bostandzic et al (2014) found that banks with higher levels of Tier 1 capital had lower exposure and contribution to global systemic risk. Further, they found that bank size and interconnectedness are positively related to global financial fragility. They also found that deposit insurance schemes that require banks and depositors to bear more financial risk are associated with greater vulnerability and contribution to a crisis of the financial sector. van Oordt and Zhou (2015) found that banks with higher non-performing loan ratios and lower profitability ratios tended to have higher tail risk, while larger banks, with higher trading revenue, and higher non-interest income tend to have higher systemic risk. Laeven et al (2016) found that systemic risk increases with bank size and is inversely related with bank capital; in particular, low capital in large banks is the key driver of systemic risk. Further, they found that market-based activities and country characteristics have moderating effect on these relationships. Anghelache and Oanea (2016) found that financial leverage, size, risk, and market to book value had a significant impact on systemic risk contribution of Romanian commercial banks.

Some studies have examined the impact of bank capital on systemic risk. Dhumale (2000) suggested that controlling individual banks' capital adequacy can decrease their impact on the fragility of the banking system, i.e. systemic risk. de Jonghe (2010) found that a bank's exposure to systemic risk is reduced by higher capital. Miles et al (2012) suggested that higher capital reduces the probability of banking crises. Jarrow (2012) argued that the basis of the Basel III capital adequacy rules, viz. Value-at-Risk (VaR), leverage ratios, and stress testing, provide an incentive to increase the probability of catastrophic bank failure, thus increasing systemic risk. He further argued that the 2007-09 crisis was an unintended consequence of the Basel II VaR capital adequacy rules. He proposed that these capital adequacy rules be replaced by one based on a risk measure related to the conditional expected loss given insolvency. De Haan and Klomp (2015) found that capital regulations increased the "capital and asset risk" of banks operating in emerging and developing countries, with a stronger relation in case of low capitalized or riskier banks.

The role of capital adequacy in systemic risk is ambiguous from the literature. Higher capital adequacy is expected to decrease a bank's systemic impact, however, it may also increase bank risk-taking. Following Jarrow (2012), the study proposes neutral systemic risk as a criterion for capital adequacy.

\section{Methodology}

The objective of the study is to analyse the role of capital adequacy in systemic risk for banks in India. Due to the wide differences in performance between public sector and private sector banks, the determinants of systemic risk would be expected to differ between public sector and private sector banks. 


\section{Ml Macrothink}

Asian Journal of Finance \& Accounting ISSN 1946-052X

The study was conducted using sample of thirty-two Indian banks, including twenty-one public sector banks, and ten private sector banks. The list of sample banks is given in the table below.

\begin{tabular}{|l|l|}
\hline Public sector banks & Private sector banks \\
\hline Allahabad Bank & Axis Bank Ltd \\
\hline Andhra Bank & Federal Bank Ltd \\
\hline Bank of Baroda & HDFC Bank Ltd \\
\hline Bank of India & ICICI Bank Ltd \\
\hline Bank of Maharashtra & IndusInd Bank Ltd \\
\hline Canara Bank & Jammu \& Kashmir Bank Ltd \\
\hline Central Bank of India & Karnataka Bank Ltd \\
\hline Corporation Bank & Karur Vysya Bank Ltd \\
\hline Dena Bank & Kotak Mahindra Bank Ltd \\
\hline IDBI Bank Ltd & Yes Bank Ltd \\
\hline Indian Bank & \\
\hline Indian Overseas Bank & \\
\hline Punjab \& Sind Bank & \\
\hline Punjab National Bank & \\
\hline State Bank of Bikaner \& Jaipur & \\
\hline State Bank of India & \\
\hline State Bank of Mysore & \\
\hline State Bank of Travancore & \\
\hline Syndicate Bank & \\
\hline United Commercial Bank & \\
\hline Union Bank of India & \\
\hline Vijaya Bank & \\
\hline
\end{tabular}

The data pertaining to bank characteristics was collected from the Capitaline database (www.Capitaline.com). The SRISK estimates were collected from NYU Stern's V-Lab database (https://vlab.stern.nyu.edu/analysis/RISK.WORLDFIN-MR.GMES). The study period was 2007-16.

The dependent variable considered for the study is the measure of systemic risk proposed by Brownlees and Engle (2012), SRISK. This index measures the expected capital shortage faced by a bank during a period of system distress when the market declines substantially. It is estimated as

$$
\operatorname{SRISK}_{i, t}=k D_{i, t}-(1-k) W_{i, t}\left(1-\operatorname{LRMES}_{i, t+h \mid t}\left(C_{t+h \mid t}\right)\right),
$$

where $\mathrm{k}$ is the minimum fraction of capital (as a ratio of total assets) each bank needs to hold, $\mathrm{D}_{\mathrm{i}, \mathrm{t}}$ and $\mathrm{W}_{\mathrm{i}, \mathrm{t}}$ are the book value of its debt (total liabilities) and the market value of its equity, respectively, and the long-run marginal expected shortfall LRMES is defined as the tail expectation of the firm's equity return conditional on a market decline 


$$
\operatorname{LRMES}_{i, t+h \mid t}=-E_{t}\left(R_{i, t+h \mid t} \mid R_{m, t+h \mid t}<C\right) .
$$

Note that SRISK can take negative values. A bank with negative SRISK represents a well-capitalised bank with large enough capital buffers to easily absorb systemic shocks. The total systemic risk in the financial system is measured by aggregating the positive SRISK contributions of different financial institutions.

The study focuses on the role of capital adequacy in systemic risk (Laeven et al, 2014). The measure for capital adequacy used for the study is the Capital Adequacy Ratio. It is expected that higher levels of capital adequacy would be associated with a lower systemic risk. Other moderating variables considered for the study are discussed in the following.

The most common determinant for systemic risk is that of bank size, and the commonly-used proxy for size is the logarithm of the bank's total assets (see for example, Laeven et al, 2014). The systemic risk of a bank would be expected to increase with bank size. This reflects the "too big to fail" hypothesis, that the failure of a large bank would have too a great impact on the entire financial system, so that government should intervene to prevent such a failure. Consequently, the capital requirement for large banks would be expected to be larger than for small banks.

Non-performing loans is an important determinant of systemic risk (van Oordt and Zhou, 2015), and would be expected to play a role in increasing systemic risk particularly for public sector banks. The measure considered in the study is the Net Non-Performing Loans to Net Advances. A bank with a larger proportion of non-performing assets would be expected to have higher systemic risk than a bank with a smaller proportion of non-performing assets, and would thus be expected to have a larger capital requirement.

Another important determinant of systemic risk is leverage (Anghelache and Oanea, 2016). This has also been included in the present study. This would be expected to be positively related with systemic risk.

Laeven et al (2014) have also considered deposits to total assets and loans \& advances to total assets in their analysis. These have also been included in the present study, along with investments to total assets.

The study used a fixed effects panel regression model for explaining systemic risk, formulated as follows:

$$
\operatorname{SRISK}_{i, t}=a+\sum_{j} b_{j} x_{i j, t}+\sum_{j} c_{j} D_{j}+\sum_{t} d_{t} D_{t}+\epsilon_{i, t},
$$

where the dependent variable on the LHS is the SRISK of the ith bank at time point $t, \mathrm{x}_{\mathrm{ij}, \mathrm{t}}$ are the independent variables for the ith bank at time point $t$, the $D_{i}$ represent the individual bank dummies, in order to capture the bank fixed effect, and the Dt represent the year dummies, in order to capture the year fixed effect. If the model is re-expressed as 


$$
\operatorname{SRISK}_{i, t}=a+\sum_{j} b_{i} x_{i j, t}-\left(c+\sum_{j} c_{j} x_{i j, t}\right) C A R_{i, t}+\epsilon_{i, t},
$$

with $a+\sum_{j} b_{i} x_{i j, t}>0$ and $c+\sum_{j} c_{j} x_{i j, t}>0$, the condition for neutral systemic risk is given by

$$
\operatorname{CAR}_{i} \geq \frac{a+\sum_{j} b_{i} x_{i j, t}}{c+\sum_{j} c_{j} x_{i j, t}}
$$

This condition gives a simple way to set capital adequacy requirements for banks. It can be used in conjunction with other approaches suggested by Basel III for setting minimal capital adequacy requirements of banks.

The model was developed in stages. The first step was to consider Capital Adequacy Ratio on its own as the independent variable in a simple linear regression model (model Ia) and a panel regression model with bank and year fixed effects (model Ic). This is expected to yield an overall minimum level of capital adequacy, without considering other bank characteristics.

The second step was to consider Capital Adequacy Ratio and $\ln$ (total Assets) in a multiple linear regression, without interaction (model IIa) and with interaction (model IIb), as well as in a panel regression model with bank and year fixed effects, without interaction (model IIc) and with interaction (model IId). This is expected to yield a minimum level of capital adequacy, taking bank size into account.

The next steps involved Capital Adequacy Ratio and $\ln$ (total Assets) taken with different sets of moderator variables: Net Non-Performing Assets to Net Advances (models IIIa - IIId), Leverage (models IVa - IVd), Deposits to Total Assets, Loans \& Advances to Total Assets, and Investments to Total Assets (models Va - Vd). Each of these models were expected to yield minimum levels of capital adequacy, taking bank size and the different bank characteristics into account.

The final step was to consider Capital Adequacy Ratio along with all of the variables discussed above, in a multiple linear regression with interactions (model $\mathrm{VIb}$ ) and in a panel regression with bank and year fixed effects and with interactions (model VId). The final model was selected by removing insignificant variables from the above models.

\section{Findings}

The descriptive statistics for the variables are presented in Table 1 below. 
Table 1. descriptive statistics of SRISK and its determinants

\begin{tabular}{|c|c|c|c|c|c|c|c|c|}
\hline & \multicolumn{4}{|c|}{ private sector } & \multicolumn{4}{|c|}{ public sector } \\
\hline & Mean & St. Dev. & Min & Max & Mean & St. Dev. & Min & Max \\
\hline SRISK (\$ m) & -2841.41 & 5079.93 & -25319 & 3100 & 1940.70 & 2120.98 & -122 & 14521 \\
\hline Capital Adequacy Ratio & 14.78 & 2.33 & 11.03 & 22.46 & 11.92 & 1.05 & 9.44 & 15.00 \\
\hline In(Total Assets) & 13.63 & 1.11 & 11.62 & 15.80 & 14.32 & 0.86 & 12.50 & 16.93 \\
\hline Net Non-Performing Assets to Net Advances & 0.83 & 0.81 & 0.00 & 4.31 & 1.99 & 1.77 & 0.15 & 11.89 \\
\hline Leverage & 8.50 & 6.05 & 1.89 & 27.68 & 29.31 & 15.92 & 7.83 & 103.85 \\
\hline Deposits to Total Assets & 0.76 & 0.11 & 0.52 & 0.90 & 0.84 & 0.05 & 0.42 & 0.91 \\
\hline Loans \& Advances to Total Assets & 0.58 & 0.04 & 0.47 & 0.68 & 0.62 & 0.03 & 0.51 & 0.70 \\
\hline Investments to Total Assets & 0.30 & 0.04 & 0.20 & 0.43 & 0.26 & 0.03 & 0.16 & 0.34 \\
\hline
\end{tabular}

The private sector banks had a negative average SRISK and a negatively-skewed distribution of SRISK, while the public sector banks had a positive average SRISK and a positively-skewed distribution of SRISK. Private sector banks also had higher capital adequacy than public sector banks, while public sector banks had higher leverage and net non-performing assets to net advances than private sector banks. There was not much of a difference between public and private sector banks in terms of size, deposits to total assets, loans \& advances to total assets, and investments to total assets.

The relationship between capital adequacy and SRISK for private sector and public sector banks is presented in Figure 1 below.

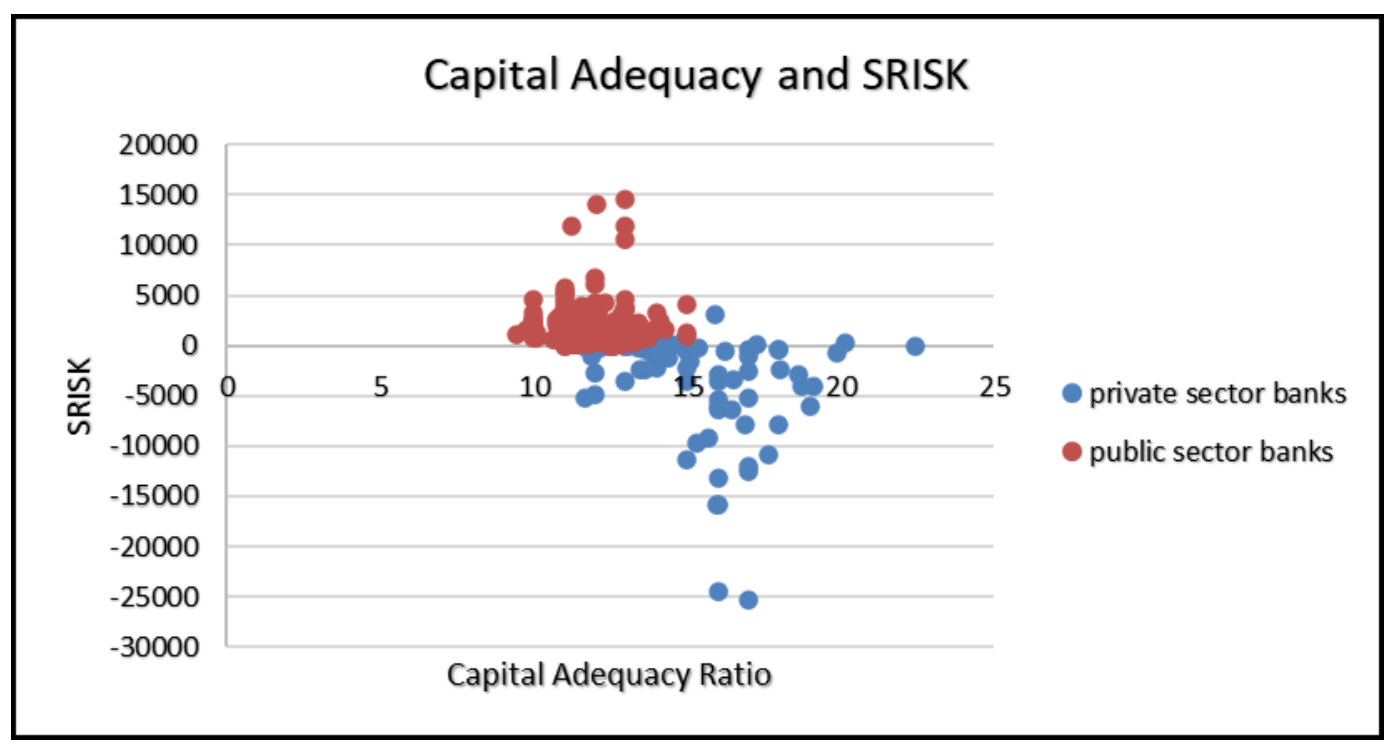

Figure 1. capital adequacy and SRISK for private sector and public sector banks

The results of model I are presented in Table 2 below. 
Table 2. model I - SRISK on Capital Adequacy Ratio

\begin{tabular}{|l|r|r|r|r|r|r|}
\hline & \multicolumn{2}{|c|}{ overall } & \multicolumn{2}{c|}{ private sector banks } & \multicolumn{2}{c|}{ public sector banks } \\
\hline & \multicolumn{1}{|c|}{ model Ia } & \multicolumn{1}{|c|}{ model Ic } & \multicolumn{1}{c|}{ model Ia } & \multicolumn{1}{c|}{ model Ic } & \multicolumn{1}{c|}{ model Ia } & \multicolumn{1}{c|}{ model Ic } \\
\hline [Intercept] & $13275.42^{* *}$ & $4654.75^{*}$ & $8380.96^{* *}$ & 1540.91 & 1503.84 & 1646.56 \\
\hline Capital Adequacy Ratio & $-1001.85^{* *}$ & $-357.57^{* *}$ & $-761.01^{* *}$ & -319.84 & 34.39 & -8.24 \\
\hline between-subjects effects & $106.16^{* *}$ & & $12.66^{* *}$ & & 0.06 & \\
\hline Capital Adequacy Ratio & & $9.94^{* *}$ & & 2.52 & & 0.01 \\
\hline bank fixed effects & & $13.03^{* *}$ & & $13.01^{* *}$ & & $18.14^{* *}$ \\
\hline year fixed effects & & $2.71^{* *}$ & & $5.33^{* *}$ & & $9.23^{* *}$ \\
\hline $\mathbf{R}^{\mathbf{2}}$ & $26.20 \%$ & $72.50 \%$ & $12.10 \%$ & & $0.00 \%$ & $73.00 \%$ \\
\hline min CAR & $13.25 \%$ & $13.02 \%$ & $11.01 \%$ & & & \\
\hline
\end{tabular}

The results of model I indicate a significant negative impact of capital adequacy on systemic risk, overall as well as for private sector banks; however, the relationship was not significant for public sector banks. The results of model Ia yielded an estimate of $13.25 \%$ as the minimum level of Capital Adequacy Ratio for neutral systemic risk. Similarly, model Ib yielded an estimate of $13.02 \%$ as the minimum level of Capital Adequacy Ratio for neutral systemic risk for the base level; estimates for other banks can be obtained by the bank dummy variable coefficient to the constant term. For example, taking the worst case (viz. State Bank of India), the estimate for the minimum level of Capital Adequacy Ratio for neutral systemic risk becomes $34.19 \%$. For private sector banks, the results of model Ia yielded an estimate of $11.01 \%$ for the minimum level of Capital Adequacy Ratio for neutral systemic risk. For public sector banks, the estimates for the minimum level of Capital Adequacy Ratio for neutral systemic risk were unreliable, as the regression results were not significant.

The results of model II for all banks are presented in Table 3a below.

Table 3a. model II - SRISK on Capital Adequacy Ratio and ln(TA), all banks

\begin{tabular}{|l|r|r|r|r|}
\hline & \multicolumn{1}{|c|}{ model IIa } & \multicolumn{1}{c|}{ model IIb } & \multicolumn{1}{c|}{ model IIc } & \multicolumn{1}{c|}{ model IId } \\
\hline [Intercept] & $6830.32^{*}$ & $-143591.93^{* *}$ & $60573.81^{* *}$ & $-49424.36^{*}$ \\
\hline Capital Adequacy Ratio & $-990.98^{* *}$ & $10471.27^{* *}$ & $-305.24^{* *}$ & $7421.68^{* *}$ \\
\hline In(Total Assets) & $447.13^{*}$ & $11159.18^{* *}$ & -4110.37 & $3719.10^{*}$ \\
\hline In(Total Assets)* Capital Adequacy Ratio & & $-816.81^{* *}$ & & $-552.14^{* *}$ \\
\hline between-subjects effects & $56.32^{* *}$ & $85.80^{* *}$ & & \\
\hline Capital Adequacy Ratio & & & $7.57^{* *}$ & $44.31^{* *}$ \\
\hline In(Total Assets) & & & $16.58^{* *}$ & $6.50^{*}$ \\
\hline In(Total Assets)* Capital Adequacy Ratio & & & & $48.43^{* *}$ \\
\hline bank fixed effects & & & $13.61 * *$ & $10.24 * *$ \\
\hline year fixed effects & & & $4.36^{* *}$ & $4.49^{* *}$ \\
\hline $\mathbf{R}^{2}$ & $27.40 \%$ & $46.40 \%$ & $71.40 \%$ & $78.20 \%$ \\
\hline
\end{tabular}




\section{MInstitute Macrothink $_{\text {Int }}$}

The results of model IIa indicate a significant negative impact of capital adequacy on systemic risk and a significant positive impact of size on systemic risk. The estimates for the minimum level of Capital Adequacy Ratio for neutral systemic risk vary from $12.13 \%$ to $14.53 \%$ (the worst case again being State Bank of India). The results of model IIb indicate, further, a significant negative interaction effect of capital adequacy and size on systemic risk. The estimates for the minimum level of Capital Adequacy Ratio for neutral systemic risk vary from $13.50 \%$ to $14.21 \%$. The results of model IIc were similar to the results of model Ic, as size was not significant in the model; for example, the estimate for the minimum level of Capital Adequacy Ratio for neutral systemic risk for State Bank of India from this model was $38.14 \%$. The results of model IId were similar to the results of model IIb; for example, for State Bank of India, the estimate for the minimum level of Capital Adequacy Ratio for neutral systemic risk from this model was $16.50 \%$.

The results of model II for private sector banks and public sector banks are presented in Table $3 \mathrm{~b}$ and Table $3 \mathrm{c}$ below.

Table 3b. model II - SRISK on Capital Adequacy Ratio and ln(TA), private sector banks

\begin{tabular}{|l|r|r|r|r|}
\hline & \multicolumn{1}{|c|}{ model IIa } & \multicolumn{1}{c|}{ model IIb } & \multicolumn{1}{c|}{ model IIc } & \multicolumn{1}{c|}{ model IId } \\
\hline [Intercept] & $38683.99 * *$ & -47939.06 & 27879.14 & -61707.43 \\
\hline Capital Adequacy Ratio & -295.42 & $5364.62 *$ & -298.22 & $7324.23 * *$ \\
\hline In(Total Assets) & $-2726.98 * *$ & 3818.11 & -1911.80 & 4817.38 \\
\hline In(Total Assets)* Capital Adequacy Ratio & & $-426.17 *$ & & $-563.37 * *$ \\
\hline between-subjects effects & $34.50 * *$ & $25.87 * *$ & & \\
\hline Capital Adequacy Ratio & & & 2.19 & $10.18 * *$ \\
\hline In(Total Assets) & & & 1.34 & 3.58 \\
\hline In(Total Assets)* Capital Adequacy Ratio & & & & $11.10 * *$ \\
\hline bank fixed effects & & & $6.98 * *$ & $8.21 * *$ \\
\hline year fixed effects & & & $2.08 *$ & $2.11 *$ \\
\hline $\mathbf{R}^{2}$ & $43.10 \%$ & $46.30 \%$ & $73.20 \%$ & $76.80 \%$ \\
\hline
\end{tabular}

Table 3c. model II - SRISK on Capital Adequacy Ratio and $\ln (\mathrm{TA})$, public sector banks

\begin{tabular}{|l|r|r|r|r|}
\hline & \multicolumn{1}{c|}{ model IIa } & \multicolumn{1}{c|}{ model IIb } & \multicolumn{1}{c|}{ model IIc } & \multicolumn{1}{c|}{ model IId } \\
\hline [Intercept] & $-25090.26 * *$ & 18530.08 & -35941.42 & -6877.863 \\
\hline Capital Adequacy Ratio & -37.82 & $-3680.10^{*}$ & -3.68 & -2332.747 \\
\hline In(Total Assets) & $1919.78^{* *}$ & -1101.19 & $2641.15^{*}$ & 630.548 \\
\hline In(Total Assets)* Capital Adequacy Ratio & & $252.18^{*}$ & & 160.863 \\
\hline between-subjects effects & $158.70^{* *}$ & $109.32 * *$ & & \\
\hline Capital Adequacy Ratio & & & 0.00 & 1.75 \\
\hline In(Total Assets) & & & $4.07 *$ & 0.10 \\
\hline In(Total Assets)* Capital Adequacy Ratio & & & & 1.75 \\
\hline bank fixed effects & & & $2.75 * *$ & $2.63 * *$ \\
\hline year fixed effects & & & $2.52 *$ & $2.45 *$ \\
\hline $\mathbf{R}^{2}$ & $60.90 \%$ & $61.80 \%$ & $73.60 \%$ & $73.90 \%$ \\
\hline
\end{tabular}




\section{NI Macrothink}

Asian Journal of Finance \& Accounting ISSN 1946-052X 2020, Vol. 12, No. 1

For private sector banks, the results of model IIa indicate a significant negative impact of size on systemic risk, while for public sector banks, the results of model IIa and model IIc indicate a significant positive impact of size on systemic risk. For private sector banks, the results of model IIa, IIb, and IId yielded estimates of $15.56 \%, 9.03 \%$, and $11.05 \%$, respectively, for the minimum level of Capital Adequacy Ratio for neutral systemic risk. For public sector banks, the estimates for the minimum level of Capital Adequacy Ratio for neutral systemic risk were unreliable, as the regression results were not significant.

The results of model III for all banks are presented in Table 4a below.

Table 4a. model III - SRISK on Capital Adequacy Ratio, ln(TA), and Net Non-Performing Assets to Net Advances, all banks

\begin{tabular}{|c|c|c|c|c|}
\hline & model IIIa & model IIIb & model IIIc & model IIId \\
\hline [Intercept] & $7438.62 *$ & $-149863.09 * *$ & 24722.79 & $-70612.28 * *$ \\
\hline Capital Adequacy Ratio & $-900.72 * *$ & $10989.84 * *$ & -197.11 & $6344.60 * *$ \\
\hline In(Total Assets) & 283.80 & $11929.56^{* *}$ & -1812.12 & $5420.74 * *$ \\
\hline Net Non-Performing Assets to Net Advances & $330.60 *$ & $-4395.67 * *$ & $846.41 * *$ & $-2521.54 * *$ \\
\hline In(Total Assets)* Capital Adequacy Ratio & & $-881.65^{* *}$ & & $-493.72 * *$ \\
\hline Net Non-Performing Assets to Net Advances* & & & & \\
\hline Capital Adequacy Ratio & & $387.89 * *$ & & $278.79 * *$ \\
\hline between-subjects effects & $40.11 * *$ & $63.87 * *$ & & \\
\hline Capital Adequacy Ratio & & & 3.51 & $32.57 * *$ \\
\hline In(Total Assets) & & & 3.18 & $14.95^{* *}$ \\
\hline Net Non-Performing Assets to Net Advances & & & $37.69 * *$ & $16.66^{* *}$ \\
\hline In(Total Assets)* Capital Adequacy Ratio & & & & $37.88 * *$ \\
\hline $\begin{array}{l}\text { Net Non-Performing Assets to Net Advances* } \\
\text { Capital Adequacy Ratio }\end{array}$ & & & & $26.41 * *$ \\
\hline bank fixed effects & & & $14.29 * *$ & $10.55^{* *}$ \\
\hline year fixed effects & & & $6.12 * *$ & $5.71 * *$ \\
\hline $\mathbf{R}^{2}$ & $28.80 \%$ & $52.00 \%$ & $77.40 \%$ & $81.50 \%$ \\
\hline
\end{tabular}

The results of model IIIa indicate a significant negative impact of capital adequacy on systemic risk and a significant positive impact of non-performing assets on systemic risk. The results of models IIIb and IIId further indicate a significant negative interaction effect between capital adequacy and size and a significant positive interaction effect between capital adequacy and non-performing assets, with estimates for the minimum level of Capital Adequacy Ratio for neutral systemic risk as $17.96 \%, 15.08 \%$, and $12.54 \%$, respectively.

The results of model III for private sector banks and public sector banks are presented in Table $4 \mathrm{~b}$ and Table $4 \mathrm{c}$ below. 
Table 4b. model III - SRISK on Capital Adequacy Ratio, ln(TA), and Net Non-Performing Assets to Net Advances, private sector banks

\begin{tabular}{|c|c|c|c|c|}
\hline & model IIIa & model IIIb & model IIIc & model IIId \\
\hline [Intercept] & $37755.22 * *$ & -55268.35 & 1644.24 & $-82966.52 *$ \\
\hline Capital Adequacy Ratio & -270.91 & $5802.10 *$ & -249.13 & $6841.34 * *$ \\
\hline $\ln$ (Total Assets) & $-2730.85^{* *}$ & 4406.02 & -177.42 & $6275.13 *$ \\
\hline Net Non-Performing Assets to Net Advances & 739.64 & -753.81 & $1728.22 * *$ & 65.45 \\
\hline In(Total Assets)* Capital Adequacy Ratio & & $-465.17 *$ & & $-530.18 * *$ \\
\hline Net Non-Performing Assets to Net Advances* & & & & \\
\hline Capital Adequacy Ratio & & 112.67 & & 113.57 \\
\hline between-subjects effects & $24.05 * *$ & $16.44 * *$ & & \\
\hline Capital Adequacy Ratio & & & 1.69 & $9.73 * *$ \\
\hline In(Total Assets) & & & 0.01 & $6.33 *$ \\
\hline Net Non-Performing Assets to Net Advances & & & $9.29 * *$ & 0.00 \\
\hline In(Total Assets)* Capital Adequacy Ratio & & & & $10.76^{* *}$ \\
\hline Net Non-Performing Assets to Net Advances* & & & & \\
\hline Capital Adequacy Ratio & & & & 0.43 \\
\hline bank fixed effects & & & $7.88 * *$ & $8.81 * *$ \\
\hline year fixed effects & & & $3.07 * *$ & $2.87 * *$ \\
\hline $\mathbf{R}^{2}$ & $44.50 \%$ & $48.30 \%$ & $76.20 \%$ & $79.50 \%$ \\
\hline
\end{tabular}

Table 4c. model III - SRISK on Capital Adequacy Ratio, ln(TA), and Net Non-Performing Assets to Net Advances, public sector banks

\begin{tabular}{|c|c|c|c|c|}
\hline & model IIIa & model IIIb & model IIIc & model IIId \\
\hline [Intercept] & $-25072.15^{* *}$ & 11578.40 & $-38101.44 *$ & -13098.77 \\
\hline Capital Adequacy Ratio & -30.13 & -3059.73 & 7.13 & -1874.74 \\
\hline In(Total Assets) & $1910.33 * *$ & -527.62 & $2756.45^{*}$ & 1130.37 \\
\hline Net Non-Performing Assets to Net Advances & 12.84 & -860.95 & 71.95 & -831.02 \\
\hline In(Total Assets)* Capital Adequacy Ratio & & 200.78 & & 117.97 \\
\hline Net Non-Performing Assets to Net Advances* & & & & \\
\hline Capital Adequacy Ratio & & 79.36 & & 86.36 \\
\hline between-subjects effects & $105.32 * *$ & $66.27 * *$ & & \\
\hline Capital Adequacy Ratio & & & 0.01 & 1.08 \\
\hline In(Total Assets) & & & $4.34 *$ & 0.31 \\
\hline Net Non-Performing Assets to Net Advances & & & 0.42 & 2.02 \\
\hline In(Total Assets)* Capital Adequacy Ratio & & & & 0.87 \\
\hline Net Non-Performing Assets to Net Advances* & & & & \\
\hline Capital Adequacy Ratio & & & & 2.56 \\
\hline bank fixed effects & & & $2.75^{* *}$ & $2.49 * *$ \\
\hline year fixed effects & & & $2.33 *$ & $2.22 *$ \\
\hline $\mathbf{R}^{2}$ & $60.90 \%$ & $62.20 \%$ & $73.70 \%$ & $74.40 \%$ \\
\hline
\end{tabular}


For private sector banks, the results of model IIIa indicate a significant negative impact of size on systemic risk, and the results of model IIIb and model IIId indicate a significant negative interaction effect between capital adequacy and size; for public sector banks, the results of model IIIa and model IIIc indicate a significant positive impact of size on systemic risk. For private sector banks, the results of model IIIb and IIId yielded estimates of $14.11 \%$ and $30.60 \%$, respectively, for the minimum level of Capital Adequacy Ratio for neutral systemic risk. For public sector banks, the estimates for the minimum level of Capital Adequacy Ratio for neutral systemic risk were unreliable, as the regression results were not significant.

The results of model IV for all banks are presented in Table 5a below.

Table 5a. model IV - SRISK on Capital Adequacy Ratio, ln(TA), and Leverage, all banks

\begin{tabular}{|l|r|r|r|r|}
\hline & model IVa & \multicolumn{1}{c|}{ model IVb } & \multicolumn{1}{c|}{ model IVc } & \multicolumn{1}{c|}{ model IVd } \\
\hline [Intercept] & 4497.84 & $-142039.97^{* *}$ & $13803.82^{* *}$ & $-49522.38^{*}$ \\
\hline Capital Adequacy Ratio & $-814.93^{* *}$ & $10189.67^{* *}$ & $-234.75^{*}$ & $7153.18^{* *}$ \\
\hline In(Total Assets) & $389.37^{*}$ & $11398.55^{* *}$ & $-3901.96^{* *}$ & $3953.06^{* *}$ \\
\hline Leverage & $39.06^{* *}$ & $-623.40^{* *}$ & $42.15^{* *}$ & $-188.45^{*}$ \\
\hline In(Total Assets)* Capital Adequacy Ratio & & $-829.16^{* *}$ & & $-550.88^{* *}$ \\
\hline Leverage * Capital Adequacy Ratio & & $55.38^{* *}$ & & $18.55^{* *}$ \\
\hline between-subjects effects & $40.88^{* *}$ & $78.15^{* *}$ & & \\
\hline Capital Adequacy Ratio & & & $4.35^{*}$ & $40.78^{* *}$ \\
\hline In(Total Assets) & & & $15.22^{* *}$ & $7.35^{* *}$ \\
\hline Leverage & & & $7.42^{* *}$ & $5.94^{*}$ \\
\hline In(Total Assets)* Capital Adequacy Ratio & & & & $46.77^{* *}$ \\
\hline Leverage* Capital Adequacy Ratio & & & & $7.64 * *$ \\
\hline bank fixed effects & & & $13.56^{* *}$ & $7.58^{* *}$ \\
\hline year fixed effects & & & $3.24^{* *}$ & $3.38^{* *}$ \\
\hline $\mathbf{R}^{2}$ & $29.20 \%$ & $57.00 \%$ & $74.80 \%$ & $79.00 \%$ \\
\hline
\end{tabular}

The results of model IVa indicate a significant negative impact of capital adequacy on systemic risk and significant positive impacts of size and leverage on systemic risk. The results of models $\mathrm{IVb}$ and IVd further indicate a significant negative interaction effect between capital adequacy and size and a significant positive interaction effect between capital adequacy and leverage. Models IVa and IVb yielded estimates of $18.59 \%$ and $7.24 \%$ for the minimum level of Capital Adequacy Ratio for neutral systemic risk. Models IVc and IVd did not yield consistent estimates for the minimum level of Capital Adequacy Ratio for neutral systemic risk, despite all coefficients being significant.

The results of model IV for private sector banks and public sector banks are presented in Table $5 \mathrm{~b}$ and Table $5 \mathrm{c}$ below. 
Table 5b. model IV - SRISK on Capital Adequacy Ratio, $\ln (\mathrm{TA})$, and Leverage, private sector banks

\begin{tabular}{|c|c|c|c|c|}
\hline & model IVa & model IVb & model IVc & model IVd \\
\hline [Intercept] & $29434.94 * *$ & -31952.56 & 24843.68 & -65278.32 \\
\hline Capital Adequacy Ratio & -106.05 & 3743.93 & -286.55 & $7389.00 * *$ \\
\hline In(Total Assets) & $-2393.00 * *$ & 3023.15 & -1744.07 & 4986.53 \\
\hline Leverage & $222.10 * *$ & $-1126.05^{*}$ & 70.50 & 139.38 \\
\hline In(Total Assets)* Capital Adequacy Ratio & & $-345.29 *$ & & $-563.52 * *$ \\
\hline Leverage * Capital Adequacy Ratio & & $100.21 * *$ & & -7.49 \\
\hline between-subjects effects & $28.11 * *$ & $22.20 * *$ & & \\
\hline Capital Adequacy Ratio & & & 1.98 & $9.02 * *$ \\
\hline In(Total Assets) & & & 1.08 & 3.43 \\
\hline Leverage & & & 0.40 & 0.06 \\
\hline In(Total Assets)* Capital Adequacy Ratio & & & & $10.36 * *$ \\
\hline Leverage* Capital Adequacy Ratio & & & & 0.03 \\
\hline bank fixed effects & & & $5.92 * *$ & $5.53 * *$ \\
\hline year fixed effects & & & 1.74 & 1.78 \\
\hline $\mathbf{R}^{2}$ & $48.40 \%$ & $55.80 \%$ & $73.3 \%$ & $76.8 \%$ \\
\hline
\end{tabular}

Table 5c. model IV - SRISK on Capital Adequacy Ratio, $\ln (\mathrm{TA})$, and Leverage, public sector banks

\begin{tabular}{|c|c|c|c|c|}
\hline & model IVa & model IVb & model IVc & model IVd \\
\hline [Intercept] & $-26033.41 * *$ & 27937.06 & -33929.90 & 883.25 \\
\hline Capital Adequacy Ratio & 16.13 & $-4522.74 * *$ & 20.51 & -2872.88 \\
\hline ln(Total Assets) & $1921.82 * *$ & -1598.61 & 2458.35 & 183.68 \\
\hline Leverage & 9.24 & -101.86 & 8.84 & -57.03 \\
\hline In(Total Assets)* Capital Adequacy Ratio & & $298.74 *$ & & 188.03 \\
\hline Leverage * Capital Adequacy Ratio & & 9.65 & & 5.76 \\
\hline between-subjects effects & $107.11 * *$ & $67.61 * *$ & & \\
\hline Capital Adequacy Ratio & & & 0.04 & 2.40 \\
\hline In(Total Assets) & & & 3.44 & 0.01 \\
\hline Leverage & & & 0.79 & 0.62 \\
\hline In(Total Assets)* Capital Adequacy Ratio & & & & 2.28 \\
\hline Leverage* Capital Adequacy Ratio & & & & 0.86 \\
\hline bank fixed effects & & & $2.76 * *$ & $2.53 *$ \\
\hline year fixed effects & & & 1.60 & 1.39 \\
\hline $\mathbf{R}^{2}$ & $61.30 \%$ & $62.70 \%$ & $73.80 \%$ & $74.20 \%$ \\
\hline
\end{tabular}

For private sector banks, the results of model IVa indicate a significant negative impact of size on systemic risk and a significant positive impact of leverage on systemic risk, and the results of model IVb and model IVd indicate a significant negative interaction effect between capital adequacy and size and a significant positive interaction effect between capital 


\section{Macrothink}

Asian Journal of Finance \& Accounting ISSN 1946-052X 2020, Vol. 12, No. 1

adequacy and leverage; for public sector banks, the results of model IVa indicate a significant positive impact of size on systemic risk, and the results of model IVb indicate a significant positive interaction effect of capital adequacy and size. For private sector banks, the results of model IVb and IVd yielded estimates of $11.77 \%$ and $11.48 \%$, respectively, for the minimum level of Capital Adequacy Ratio for neutral systemic risk. For public sector banks, the estimates for the minimum level of Capital Adequacy Ratio for neutral systemic risk were unreliable, as the regression results were not significant.

The results of model V for all banks are presented in Table 6a below.

Table 6a. model V - SRISK on Capital Adequacy Ratio, ln(TA), Deposits to Total Assets, Loans \& Advances to Total Assets, and Investments to Total Assets, all banks

\begin{tabular}{|c|c|c|c|c|}
\hline & model Va & model Vb & model Ve & model Vd \\
\hline [Intercept] & -2811.29 & $-170408.19 * *$ & $74250.33^{* *}$ & -57142.74 \\
\hline Capital Adequacy Ratio & $-820.33 * *$ & $12824.40 * *$ & $-319.21 * *$ & $9122.53 * *$ \\
\hline In(Total Assets) & $628.58 * *$ & $10390.25 * *$ & $-3882.81 * *$ & 2415.33 \\
\hline Deposits to Total Assets Ratio & $8041.09 * *$ & -24988.86 & -1697.73 & -22936.79 \\
\hline Loans \& Advances to Total Assets Ratio & -3304.98 & 94967.26 & $-24203.98 * *$ & 71704.85 \\
\hline Investments to Total Assets Ratio & 1336.50 & -4708.11 & -7386.49 & -212.08 \\
\hline In(Total Assets)* Capital Adequacy Ratio & & $-751.56^{* *}$ & & $-448.39 * *$ \\
\hline $\begin{array}{l}\text { Deposits to Total Assets Ratio* Capital } \\
\text { Adequacy Ratio }\end{array}$ & & $2342.03^{*}$ & & 1796.19 \\
\hline $\begin{array}{l}\text { Loans \& Advances to Total Assets Ratio* } \\
\text { Capital Adequacy Ratio }\end{array}$ & & $-8275.05^{*}$ & & $-7231.44 *$ \\
\hline $\begin{array}{l}\text { Investments to Total Assets Ratio* Capital } \\
\text { Adequacy Ratio }\end{array}$ & & -97.86 & & -797.74 \\
\hline between-subjects effects & $24.22 * *$ & $32.30 * *$ & & \\
\hline Capital Adequacy Ratio & & & $7.83 * *$ & $8.56^{* *}$ \\
\hline In(Total Assets) & & & $15.12 * *$ & 2.44 \\
\hline Deposits to Total Assets Ratio & & & 0.14 & 2.45 \\
\hline Loans \& Advances to Total Assets Ratio & & & $8.17 * *$ & 2.94 \\
\hline Investments to Total Assets Ratio & & & 0.69 & 0.00 \\
\hline In(Total Assets)* Capital Adequacy Ratio & & & & $28.03 * *$ \\
\hline $\begin{array}{l}\text { Deposits to Total Assets Ratio* Capital } \\
\text { Adequacy Ratio }\end{array}$ & & & & 3.28 \\
\hline $\begin{array}{l}\text { Loans \& Advances to Total Assets Ratio* } \\
\text { Capital Adequacy Ratio }\end{array}$ & & & & $4.96^{*}$ \\
\hline $\begin{array}{l}\text { Investments to Total Assets Ratio* Capital } \\
\text { Adequacy Ratio }\end{array}$ & & & & 0.06 \\
\hline bank fixed effects & & & $14.03 * *$ & $10.44 * *$ \\
\hline year fixed effects & & & $4.65 * *$ & $4.58 * *$ \\
\hline $\mathbf{R}^{2}$ & $29.10 \%$ & $50.00 \%$ & $75.40 \%$ & $80.00 \%$ \\
\hline
\end{tabular}




\section{$\triangle$ Macrothink}

Asian Journal of Finance \& Accounting ISSN 1946-052X 2020, Vol. 12, No. 1

The results of model $\mathrm{Va}$ indicate a significant negative impact of capital adequacy on systemic risk and significant positive impacts of size and deposits on systemic risk. The results of models $\mathrm{Vb}$ and $\mathrm{Vd}$ further indicate a significant negative interaction effect between capital adequacy and size and between capital adequacy and loans \& advances and a significant positive interaction effect between capital adequacy and deposits. Models Va and $\mathrm{Vb}$ yielded estimates of $16.30 \%$ and $13.08 \%$ for the minimum level of Capital Adequacy Ratio for neutral systemic risk. Models Vc and Vd did not yield consistent estimates for the minimum level of Capital Adequacy Ratio for neutral systemic risk.

The results of model $\mathrm{V}$ for private sector banks and public sector banks are presented in Table $6 \mathrm{~b}$ and Table $6 \mathrm{c}$ below.

Table 6b. model V - SRISK on Capital Adequacy Ratio, $\ln (\mathrm{TA})$, Deposits to Total Assets, Loans \& Advances to Total Assets, and Investments to Total Assets, private sector banks

\begin{tabular}{|c|c|c|c|c|}
\hline & model Va & model Vb & model Ve & model Vd \\
\hline [Intercept] & $39228.81 * *$ & $-273741.84 *$ & $68640.04 *$ & -53112.548 \\
\hline Capital Adequacy Ratio & -408.32 & $21228.20 * *$ & -393.71 & 8909.727 \\
\hline $\ln ($ Total Assets $)$ & $-2520.29 * *$ & $6749.04 *$ & -1684.00 & 5199.344 \\
\hline Deposits to Total Assets Ratio & -611.57 & 4171.26 & -12983.36 & -2799.656 \\
\hline Loans \& Advances to Total Assets Ratio & -11192.19 & $257637.59 *$ & -46803.45 & -9161.005 \\
\hline Investments to Total Assets Ratio & 17785.85 & 118236.25 & -20072.81 & -18248.088 \\
\hline In(Total Assets)* Capital Adequacy Ratio & & $-609.11 * *$ & & $-577.082 * *$ \\
\hline $\begin{array}{l}\text { Deposits to Total Assets Ratio* Capital } \\
\text { Adequacy Ratio }\end{array}$ & & -236.96 & & -314.495 \\
\hline $\begin{array}{l}\text { Loans \& Advances to Total Assets Ratio* } \\
\text { Capital Adequacy Ratio }\end{array}$ & & $-19072.48^{*}$ & & -2325.883 \\
\hline $\begin{array}{l}\text { Investments to Total Assets Ratio* Capital } \\
\text { Adequacy Ratio }\end{array}$ & & -7581.38 & & 345.259 \\
\hline between-subjects effects & $18.31 * *$ & $12.35 * *$ & & \\
\hline Capital Adequacy Ratio & & & 3.51 & 1.43 \\
\hline $\ln ($ Total Assets) & & & 1.06 & 2.99 \\
\hline Deposits to Total Assets Ratio & & & 2.00 & 0.01 \\
\hline Loans \& Advances to Total Assets Ratio & & & 3.41 & 0.01 \\
\hline Investments to Total Assets Ratio & & & 0.69 & 0.03 \\
\hline In(Total Assets)* Capital Adequacy Ratio & & & & $9.71 * *$ \\
\hline $\begin{array}{l}\text { Deposits to Total Assets Ratio* Capital } \\
\text { Adequacy Ratio }\end{array}$ & & & & 0.03 \\
\hline $\begin{array}{l}\text { Loans \& Advances to Total Assets Ratio* } \\
\text { Capital Adequacy Ratio }\end{array}$ & & & & 0.09 \\
\hline $\begin{array}{l}\text { Investments to Total Assets Ratio* Capital } \\
\text { Adequacy Ratio }\end{array}$ & & & & 0.00 \\
\hline bank fixed effects & & & $7.49 * *$ & $7.02 * *$ \\
\hline year fixed effects & & & 1.55 & 1.40 \\
\hline $\mathbf{R}^{2}$ & $48.10 \%$ & $57.00 \%$ & $75.90 \%$ & $79.70 \%$ \\
\hline
\end{tabular}


Table 6c. model V - SRISK on Capital Adequacy Ratio, $\ln (\mathrm{TA})$, Deposits to Total Assets, Loans \& Advances to Total Assets, and Investments to Total Assets, public sector banks

\begin{tabular}{|c|c|c|c|c|}
\hline & model Va & model Vb & model Vc & model Vd \\
\hline [Intercept] & $-20408.50 * *$ & $105413.74 *$ & -30580.96 & 19630.69 \\
\hline Capital Adequacy Ratio & -56.76 & $-10461.04 *$ & 6.50 & -4437.12 \\
\hline $\ln$ (Total Assets) & $1839.23 * *$ & -2578.02 & 2299.99 & 736.93 \\
\hline Deposits to Total Assets Ratio & -2686.37 & 3768.73 & 4625.73 & 20712.95 \\
\hline Loans \& Advances to Total Assets Ratio & -169.69 & -69549.73 & -1832.27 & -51138.40 \\
\hline Investments to Total Assets Ratio & -3601.90 & -96962.84 & $-12744.77 *$ & -52980.36 \\
\hline In(Total Assets)* Capital Adequacy Ratio & & $368.89 * *$ & & 148.15 \\
\hline $\begin{array}{l}\text { Deposits to Total Assets Ratio* Capital } \\
\text { Adequacy Ratio }\end{array}$ & & -587.70 & & -1331.64 \\
\hline $\begin{array}{l}\text { Loans \& Advances to Total Assets Ratio* } \\
\text { Capital Adequacy Ratio }\end{array}$ & & 5728.65 & & 4086.51 \\
\hline $\begin{array}{l}\text { Investments to Total Assets Ratio* Capital } \\
\text { Adequacy Ratio }\end{array}$ & & 7716.07 & & 3373.75 \\
\hline between-subjects effects & $64.20^{* * *}$ & $37.66^{* * *}$ & & \\
\hline Capital Adequacy Ratio & & & 0.00 & 0.88 \\
\hline In(Total Assets) & & & 3.03 & 0.11 \\
\hline Deposits to Total Assets Ratio & & & 1.81 & 0.76 \\
\hline Loans \& Advances to Total Assets Ratio & & & 0.11 & 1.26 \\
\hline Investments to Total Assets Ratio & & & $4.28^{*}$ & 0.98 \\
\hline In(Total Assets)* Capital Adequacy Ratio & & & & 1.10 \\
\hline $\begin{array}{l}\text { Deposits to Total Assets Ratio* Capital } \\
\text { Adequacy Ratio }\end{array}$ & & & & 0.57 \\
\hline $\begin{array}{l}\text { Loans \& Advances to Total Assets Ratio* } \\
\text { Capital Adequacy Ratio }\end{array}$ & & & & 1.19 \\
\hline $\begin{array}{l}\text { Investments to Total Assets Ratio* Capital } \\
\text { Adequacy Ratio }\end{array}$ & & & & 0.58 \\
\hline bank fixed effects & & & $2.85^{* *}$ & $2.46^{* *}$ \\
\hline year fixed effects & & & $3.00 * *$ & $2.93 * *$ \\
\hline $\mathbf{R}^{2}$ & $61.50 \%$ & $63.20 \%$ & $74.60 \%$ & $75.00 \%$ \\
\hline
\end{tabular}

For private sector banks, the results of model $\mathrm{Va}$ indicate a significant negative impact of size on systemic risk, and the results of model $\mathrm{Vb}$ and model $\mathrm{Vd}$ indicate a significant negative interaction effect between capital adequacy and size and a significant negative interaction effect between capital adequacy and loans \& advances; for public sector banks, the results of model $\mathrm{Va}$ indicate a significant positive impact of size on systemic risk, the results of model $\mathrm{Vb}$ indicate a significant positive interaction effect of capital adequacy and size, and the results of model Vc indicate a significant negative impact of investments on systemic risk. For private sector banks, the results of model IVb yielded an estimate of $12.80 \%$ for the minimum level of Capital Adequacy Ratio for neutral systemic risk; other models did not yield consistent estimates of the minimum level of Capital Adequacy Ratio for neutral 


\section{Macrothink Mnstitutem}

Asian Journal of Finance \& Accounting ISSN 1946-052X 2020, Vol. 12, No. 1

systemic risk, as the coefficients were not significant. For public sector banks, the estimates for the minimum level of Capital Adequacy Ratio for neutral systemic risk were unreliable, as the regression results were not significant.

The results of model VI for all banks are presented in Table 7a below.

Table 7a. model VI - final model, all banks

\begin{tabular}{|c|c|c|c|c|}
\hline & model VIb & $\begin{array}{l}\text { model VIb } \\
\text { stepwise }\end{array}$ & model VId & $\begin{array}{c}\text { model VId } \\
\text { modified }\end{array}$ \\
\hline [Intercept] & $-162071.31 * *$ & $-190206.01 * *$ & $-89333.10^{* *}$ & $-84769.64 * *$ \\
\hline Capital Adequacy Ratio & $12087.64 * *$ & $14405.14^{* *}$ & $8286.33^{* *}$ & $7954.14 * *$ \\
\hline $\ln ($ Total Assets $)$ & $10934.11 * *$ & $11453.04 * *$ & $4846.45 * *$ & $4862.68 * *$ \\
\hline Net Non-Performing Assets to Net Advances & $-2746.07 * *$ & $-2274.20 * *$ & $-2279.23 * *$ & $-2768.90 * *$ \\
\hline Leverage & $-582.25 * *$ & $-651.30 * *$ & -138.53 & \\
\hline Deposits to Total Assets Ratio & -4331.72 & & & \\
\hline Loans \& Advances to Total Assets Ratio & 71261.29 & $86726.95 * *$ & $48179.58 *$ & $36888.55^{*}$ \\
\hline Investments to Total Assets Ratio & -33302.55 & & & \\
\hline In(Total Assets)* Capital Adequacy Ratio & $-793.77 * *$ & $-836.54 * *$ & $-447.45 * *$ & $-449.58 * *$ \\
\hline $\begin{array}{l}\text { Net Non-Performing Assets to Net Advances* } \\
\text { Capital Adequacy Ratio }\end{array}$ & $252.77 * *$ & $209.52 * *$ & $248.61 * *$ & $290.63 * *$ \\
\hline Leverage* Capital Adequacy Ratio & $50.79 * *$ & $56.94 * *$ & 11.64 & \\
\hline $\begin{array}{l}\text { Deposits to Total Assets Ratio* Capital } \\
\text { Adequacy Ratio }\end{array}$ & 565.86 & & & \\
\hline $\begin{array}{l}\text { Loans \& Advances to Total Assets Ratio* } \\
\text { Capital Adequacy Ratio }\end{array}$ & -6404.31 & $-7500.38 * *$ & $-4654.49 * *$ & $-3811.32 *$ \\
\hline $\begin{array}{l}\text { Investments to Total Assets Ratio* Capital } \\
\text { Adequacy Ratio }\end{array}$ & 2512.35 & & & \\
\hline between-subjects effects & $36.33 * *$ & $52.50 * *$ & & \\
\hline Capital Adequacy Ratio & & & $40.56^{* *}$ & $38.27 * *$ \\
\hline $\ln$ (Total Assets) & & & $12.02 * *$ & $12.24 * *$ \\
\hline Net Non-Performing Assets to Net Advances & & & $11.20^{* *}$ & $20.31 * *$ \\
\hline Leverage & & & 2.91 & \\
\hline \multicolumn{5}{|l|}{ Deposits to Total Assets Ratio } \\
\hline Loans \& Advances to Total Assets Ratio & & & $4.43^{*}$ & $3.82 *$ \\
\hline \multicolumn{5}{|l|}{ Investments to Total Assets Ratio } \\
\hline $\ln$ (Total Assets)* Capital Adequacy Ratio & & & $30.58 * *$ & $30.97 * *$ \\
\hline $\begin{array}{l}\text { Net Non-Performing Assets to Net Advances* } \\
\text { Capital Adequacy Ratio }\end{array}$ & & & $17.24 * *$ & $29.40 * *$ \\
\hline Leverage* Capital Adequacy Ratio & & & 2.71 & \\
\hline \multicolumn{5}{|l|}{$\begin{array}{l}\text { Deposits to Total Assets Ratio* Capital } \\
\text { Adequacy Ratio }\end{array}$} \\
\hline $\begin{array}{l}\text { Loans \& Advances to Total Assets Ratio* } \\
\text { Capital Adequacy Ratio }\end{array}$ & & & $7.65 * *$ & $5.59 *$ \\
\hline \multicolumn{5}{|l|}{$\begin{array}{l}\text { Investments to Total Assets Ratio* Capital } \\
\text { Adequacy Ratio }\end{array}$} \\
\hline bank fixed effects & & & $8.38 * *$ & $11.31 * *$ \\
\hline year fixed effects & & & $4.05^{* *}$ & $4.89 * *$ \\
\hline $\mathbf{R}^{2}$ & $62.20 \%$ & $61.90 \%$ & $82.60 \%$ & $82.40 \%$ \\
\hline
\end{tabular}




\section{I Macrothink}

Asian Journal of Finance \& Accounting ISSN 1946-052X 2020, Vol. 12, No. 1

The results of model VIb indicate that size and loans \& advances have a significant negative interaction effect with capital adequacy and non-performing assets and leverage have a significant positive interaction effect with capital adequacy on systemic risk. The results of model VId further indicate a significant negative interaction effect between capital adequacy and size and between capital adequacy and loans \& advances and a significant positive interaction effect between capital adequacy and non-performing assets, controlling for bank and year fixed effects. The models yielded estimates of $9.51 \%$ and $9.88 \%$ for the minimum level of Capital Adequacy Ratio for neutral systemic risk.

The results of model VI for private sector banks and public sector banks are presented in Table $7 \mathrm{~b}$ and Table $7 \mathrm{c}$ below.

Table 7b. model VI - final model, private sector banks

\begin{tabular}{|c|c|c|c|c|}
\hline & model VIb & $\begin{array}{l}\text { model VIb } \\
\text { stepwise }\end{array}$ & model VId & $\begin{array}{c}\text { model VId } \\
\text { modified }\end{array}$ \\
\hline [Intercept] & -170927.10 & $-136776.66^{* *}$ & -71403.32 & $-80739.40^{*}$ \\
\hline Capital Adequacy Ratio & 13104.40 & $11682.61 * *$ & $8282.17 * *$ & $8316.11 * *$ \\
\hline $\ln$ (Total Assets) & 5485.69 & $4509.35^{*}$ & $6275.84 *$ & $6377.49^{*}$ \\
\hline Net Non-Performing Assets to Net Advances & -170.73 & $-1469.17 * *$ & 2750.50 & -12.71 \\
\hline Leverage & $-1954.25 * *$ & $-136776.66^{* *}$ & -235.82 & \\
\hline Deposits to Total Assets Ratio & 33170.57 & & & \\
\hline Loans \& Advances to Total Assets Ratio & 140162.55 & $155323.50 * *$ & -18082.58 & $-4568.86 * *$ \\
\hline Investments to Total Assets Ratio & 36124.03 & & & \\
\hline In(Total Assets)* Capital Adequacy Ratio & $-503.13 *$ & $-442.13 * *$ & $-581.84 * *$ & -565.36 \\
\hline $\begin{array}{l}\text { Net Non-Performing Assets to Net Advances* } \\
\text { Capital Adequacy Ratio }\end{array}$ & 56.73 & $67.17 *$ & -52.14 & 106.15 \\
\hline Leverage* Capital Adequacy Ratio & 157.98 & $119.58 * *$ & 0.86 & \\
\hline $\begin{array}{l}\text { Deposits to Total Assets Ratio* Capital } \\
\text { Adequacy Ratio }\end{array}$ & -2681.87 & & & \\
\hline $\begin{array}{l}\text { Loans \& Advances to Total Assets Ratio* } \\
\text { Capital Adequacy Ratio }\end{array}$ & -9725.97 & $-12080.19 * *$ & -1185.32 & -1772.74 \\
\hline $\begin{array}{l}\text { Investments to Total Assets Ratio* Capital } \\
\text { Adequacy Ratio }\end{array}$ & -1297.56 & & & \\
\hline between-subjects effects & $12.59^{* *}$ & $18.85^{* *}$ & & \\
\hline Capital Adequacy Ratio & & & $7.57 * *$ & $7.88 * *$ \\
\hline $\ln ($ Total Assets) & & & $6.44^{*}$ & $6.98 *$ \\
\hline Net Non-Performing Assets to Net Advances & & & 0.93 & 0.00 \\
\hline Leverage & & & 0.19 & \\
\hline Deposits to Total Assets Ratio & & & & \\
\hline Loans \& Advances to Total Assets Ratio & & & 0.09 & 0.01 \\
\hline Investments to Total Assets Ratio & & & & \\
\hline In(Total Assets)* Capital Adequacy Ratio & & & $13.22 * *$ & $12.96^{* *}$ \\
\hline Net Non-Performing Assets to Net Advances* & & & 0.07 & 0.40 \\
\hline
\end{tabular}




\section{Macrothink}

Asian Journal of Finance \& Accounting

ISSN 1946-052X 2020, Vol. 12, No. 1

\begin{tabular}{|l|r|r|r|}
\hline Capital Adequacy Ratio & & & \\
\hline Leverage* Capital Adequacy Ratio & & & 0.00 \\
\hline $\begin{array}{l}\text { Deposits to Total Assets Ratio* Capital } \\
\text { Adequacy Ratio }\end{array}$ & & & \\
\hline $\begin{array}{l}\text { Loans \& Advances to Total Assets Ratio* } \\
\text { Capital Adequacy Ratio }\end{array}$ & & & 0.10 \\
\hline $\begin{array}{l}\text { Investments to Total Assets Ratio* Capital } \\
\text { Adequacy Ratio }\end{array}$ & & & \\
\hline bank fixed effects & & & \\
\hline year fixed effects & & & \\
\hline R $^{2}$ & & & \\
\hline
\end{tabular}

For the private sector banks, the results of model VIb indicate that size and loans \& advances have a significant negative interaction effect with capital adequacy and non-performing assets and leverage have a significant positive interaction effect with capital adequacy on systemic risk. The results of model VId further indicate a significant negative interaction effect between capital adequacy and size, controlling for bank and year fixed effects. The models yielded estimates of $12.49 \%$ and $11.63 \%$ for the minimum level of Capital Adequacy Ratio for neutral systemic risk. 
Table 7c. model VI - final model, public sector banks

\begin{tabular}{|c|c|c|c|}
\hline & model VIb & $\begin{array}{l}\text { model VIb } \\
\text { stepwise }\end{array}$ & model VId \\
\hline [Intercept] & $105544.65^{*}$ & $-177072.01 * *$ & -25444.38 \\
\hline Capital Adequacy Ratio & $-10396.01 *$ & $12777.39 * *$ & -1049.90 \\
\hline $\ln ($ Total Assets) & -2906.25 & $12030.28 * *$ & 688.33 \\
\hline Net Non-Performing Assets to Net Advances & -90.50 & & \\
\hline Leverage & -80.13 & $-785.11 * *$ & -64.77 \\
\hline Deposits to Total Assets Ratio & 3238.94 & $37324.15 * *$ & 22583.00 \\
\hline Loans \& Advances to Total Assets Ratio & -61511.10 & & \\
\hline Investments to Total Assets Ratio & -89877.30 & & \\
\hline In(Total Assets)* Capital Adequacy Ratio & $397.72 * *$ & $-876.18 * *$ & 154.56 \\
\hline $\begin{array}{l}\text { Net Non-Performing Assets to Net Advances* } \\
\text { Capital Adequacy Ratio }\end{array}$ & 6.57 & & \\
\hline Leverage* Capital Adequacy Ratio & 8.04 & $68.67 * *$ & 6.36 \\
\hline $\begin{array}{l}\text { Deposits to Total Assets Ratio* Capital } \\
\text { Adequacy Ratio }\end{array}$ & -586.75 & $-2795.57 * *$ & -1598.92 \\
\hline $\begin{array}{l}\text { Loans \& Advances to Total Assets Ratio* } \\
\text { Capital Adequacy Ratio }\end{array}$ & 4936.99 & & \\
\hline $\begin{array}{l}\text { Investments to Total Assets Ratio* Capital } \\
\text { Adequacy Ratio }\end{array}$ & 7055.82 & & \\
\hline between-subjects effects & $26.74 * *$ & $58.59 * *$ & \\
\hline Capital Adequacy Ratio & & & 0.16 \\
\hline $\ln$ (Total Assets) & & & 0.11 \\
\hline \multicolumn{4}{|l|}{ Net Non-Performing Assets to Net Advances } \\
\hline Leverage & & & 0.76 \\
\hline Deposits to Total Assets Ratio & & & 0.89 \\
\hline \multicolumn{4}{|l|}{ Loans \& Advances to Total Assets Ratio } \\
\hline \multicolumn{4}{|l|}{ Investments to Total Assets Ratio } \\
\hline In(Total Assets)* Capital Adequacy Ratio & & & 1.39 \\
\hline \multicolumn{4}{|l|}{$\begin{array}{l}\text { Net Non-Performing Assets to Net Advances* } \\
\text { Capital Adequacy Ratio }\end{array}$} \\
\hline Leverage* Capital Adequacy Ratio & & & 0.89 \\
\hline $\begin{array}{l}\text { Deposits to Total Assets Ratio* Capital } \\
\text { Adequacy Ratio }\end{array}$ & & & 0.80 \\
\hline \multicolumn{4}{|l|}{$\begin{array}{l}\text { Loans \& Advances to Total Assets Ratio* } \\
\text { Capital Adequacy Ratio }\end{array}$} \\
\hline \multicolumn{4}{|l|}{$\begin{array}{l}\text { Investments to Total Assets Ratio* Capital } \\
\text { Adequacy Ratio }\end{array}$} \\
\hline bank fixed effects & & & $2.44 * *$ \\
\hline year fixed effects & & & 1.42 \\
\hline $\mathbf{R}^{2}$ & $64.30 \%$ & $58.30 \%$ & $74.30 \%$ \\
\hline
\end{tabular}


For the public sector banks, the results of model VIb indicate that size and deposits have a significant negative interaction effect with capital adequacy and leverage has a significant positive interaction effect with capital adequacy on systemic risk. The results of model VId further indicate no significant variables, controlling for bank and year fixed effects. The models yielded estimates of $8.29 \%$ and $9.96 \%$ for the minimum level of Capital Adequacy Ratio for neutral systemic risk.

\section{Discussion}

The study contributes to the literature by proposing the concept of minimum level of capital adequacy for neutral systemic risk, which is the level of capital adequacy for which the systemic risk is non-positive. This arises from the negative relationship between systemic risk and capital adequacy, as discussed in the methodology.

The results of the study indicate that capital adequacy has a significant negative impact on systemic risk. Further, many of the variables considered were significant moderators of the relationship between capital adequacy and systemic risk. Bank size was found to have a significant positive impact on systemic risk and a significant negative interaction effect with capital adequacy, so that the minimum capital adequacy for neutral systemic risk was found to increase with bank size. Net Non-Performing Assets to Net Advances was found to have a significant positive impact on systemic risk and a significant positive interaction effect with capital adequacy, so that the minimum capital adequacy for neutral systemic risk was found to increase with non-performing assets. Leverage was found to have a significant positive impact on systemic risk and a significant positive interaction effect with capital adequacy, so that the minimum capital adequacy for neutral systemic risk was found to increase with leverage. Deposits to Total Assets was found to have a significant positive impact on systemic risk and a significant positive interaction effect with capital adequacy, so that the minimum capital adequacy for neutral systemic risk was found to increase with deposits. Loans \& Advances to Total Assets was found to have a significant negative impact on systemic risk, but it had a significant negative interaction effect with capital adequacy, so that the minimum capital adequacy for neutral systemic risk was found to decrease with loans \& advances. Investments to Total Assets was not found to have a significant impact on systemic risk and consequently on the minimum capital adequacy for neutral systemic risk. In the final model, bank size, non-performing assets, leverage, and loans \& advances were found to have a significant impact on the minimum capital adequacy for neutral systemic risk.

There were significant fixed effects in the final panel regression model. The bank fixed effects were found to be significant, indicating that there were significant differences in systemic impact between the banks. In particular, the banks with highest systemic impact were State Bank of India, Bank of Baroda, and Canara Bank (all of which are public sector banks), while the banks with least systemic impact were HDFC Bank, Kotak Mahindra Bank, and ICICI Bank (all of which are private sector banks). The year fixed effects were also found to be significant, indicating significant differences in systemic impact over time. Of course, systemic impact was high in the crisis period of 2008-09, and there was found to be a significant increase in systemic impact in 2012-14 as compared with previous years. 
For private sector banks, bank size, non-performing assets, leverage, and loans \& advances were found to have a significant impact on the minimum capital adequacy for neutral systemic risk; however, controlling for bank and year fixed effects, only bank size and loans $\&$ advances were found to have significant impact on the minimum capital adequacy for neutral systemic risk; bank size was found to increase the minimum capital adequacy for neutral systemic risk, while loans $\&$ advances was found to decrease the minimum capital adequacy for neutral systemic risk. For the private sector banks, the bank fixed effects were again found to be significant, indicating that there were significant differences in systemic risk between the banks. The year fixed effects were also found to be significant, indicating a significant decrease in systemic risk in 2015-16 as compared with previous years.

For public sector banks, bank size, leverage, and deposits were found to have a significant impact on the minimum capital adequacy for neutral systemic risk; however, controlling for bank and year fixed effects, neither capital adequacy nor any of the moderating variables was found to be significant. For the public sector banks, the bank fixed effects were found to be significant, indicating that there were significant differences in systemic risk between the banks. The year fixed effects were found to be not significant.

The results of the study give a wide range of estimates for the minimum capital adequacy for neutral systemic risk, varying from $7.24 \%$ to $18.59 \%$; and for private sector banks, the estimates varied from $9.03 \%$ to $30.60 \%$. However, instead of setting a fixed capital adequacy level for all banks, the model can be used to set capital adequacy targets for individual banks with estimates or projections of the bank's characteristics. This can be used in conjunction with the Basel III framework in order to rationalise capital adequacy targets. In particular, the results of the study have identified some banks with relatively high systemic impact, viz. State Bank of India, Bank of Baroda, and Canara Bank. These banks must be monitored more carefully, and perhaps may be required to hold more capital or liquid assets to avert crisis.

Several of the findings are similar to those in the literature. Capital adequacy was found to be significant and negatively related with systemic risk, as found by Laeven et al (2016). Bank size was found to be significant and positively related with systemic risk, as suggested by several authors (Moore and Zhou, 2014; Laeven et al, 2016). Non-performing assets was found to have a significant positive impact on systemic risk, as suggested by van Oordt and Zhou (2015). Leverage was found to be significant and positively related with systemic risk, as suggested by Anghelache and Oanea (2016).

There are some limitations inherent in the study. The sample considered for the study was relatively small, and consisted of the relatively larger Indian banks. Also, the global financial crisis and Euro-zone crises had taken place during the study period, possibly contaminating the results. Further, there could be some multicollinearity between the variables, since many of the measures considered are related. For example, capital adequacy has improved in recent years, so that the significance of capital adequacy could have been affected by the year fixed effect. The results of the study thus need to be tested for robustness. There is great scope for extending the study by including other possible determinants of systemic risk. Also, as most of the variables were found to be insignificant in the models for public sector banks, the 
determinants of systemic risk in public sector banks should be analysed more carefully. Perhaps forming clusters of banks with similar trends in systemic risk and analysing determinants of systemic risk within clusters would yield better results.

\section{References}

Acharya, V.V., Brownlees, C., Engle, R., Farazmand, F., and Richardson, M. (2010). Measuring Systemic Risk. in Regulating Wall Street: The Dodd-Frank Act and the New Architecture of Global Finance, edited by Acharya, V.V., Cooley, T., Richardson, M., and Walter, I., John Wiley \& Sons. https://doi.org/10.26509/frbc-wp-201002

Acharya, V.V., Engle, R.F., and Richardson, M. (2012). Capital Shortfall: A new approach to ranking and regulating systemic risks. Presented at the American Economic Association Meeting held at Chicago, Illinois, USA on Jan 7, 2012. https://doi.org/10.1002/9781118258231.ch4

Acharya, V.V., Pedersen, L., Philippon, T., and Richardson, M. (2010). Measuring Systemic Risk. NYU Stern Working Paper. https://doi.org/10.26509/frbc-wp-201002

Acharya, V.V. and Steffen, S. (2012). Analyzing Systemic Risk of the European Banking Sector. NYU Stern Working Paper. in Handbook on Systemic Risk, edt. J.-P- Fouque and J. Langsam. Cambridge University Press.

Adrian, T. and Brunnermeier, M.K. (2008). CoVaR. Federal Reserve Bank of New York Staff Report No. 348. https://doi.org/10.2139/ssrn.1269446

Anghelache, G.-V. and Oanea, D.-C. (2016). Romanian Commercial Banks' Systemic Risk and Its Determinants: A CoVaR Approach. International Journal of Academic Research in Accounting, Finance and Management Sciences, 6(3), 96-109. https://doi.org/10.6007/IJARAFMS/v6-i3/2175

Boot, A.W.A. and Ratnovski, L. (2012). Banking and Trading. International Monetary Fund Working Paper No. 12/238. https://doi.org/10.5089/9781475511215.001

Bostandzic, D., Pelster, M., and Weiss, G.N.F. (2014). Systemic risk, bank capital, and deposit insurance around the world. SSRN Working Paper No. 2438693. https://doi.org/10.2139/ssrn.2438693

Brownlees, C.T. and Engle, R.F. (2012). Volatility, Correlation and Tails for Systemic Risk Measurement. NYU Stern Working Paper. https://doi.org/10.2139/ssrn.1611229

Brownlees, C.T. and Engle, R.F. (2017). SRISK: a conditional capital shortfall model for systemic risk. European Systemic Risk Board Working Paper. https://doi.org/10.1093/rfs/hhw060

Dash, M. and Das, A. (2013). Performance Appraisal of Indian Banks Using CAMELS Rating. IUP Journal of Bank Management, 12(2), 31-42. 


\section{$\triangle$ Macrothink}

Asian Journal of Finance \& Accounting ISSN 1946-052X

Dash, M., Kumari, G., and Anand, S. (2015). Comparison of Public and Private Sector Banking Performance using CAMELS Framework. MANAGEMENT TODAY-An International Journal of Management Studies, 5(3), 107-112. https://doi.org/10.11127/gmt.2015.09.02

de Jonghe, O. (2010). Back to the basics of banking? A micro analysis of banking system stability. Journal of Financial Intermediation, 19, 387-417. https://doi.org/10.1016/j.jfi.2009.04.001

Dhumale, R. (2000). Capital Adequacy Standards: are they sufficient? ESRC Centre for Business Research, University of Cambridge, Working Paper No. 165.

Diamond, D.W. and Rajan, R.G. (2000). A Theory of Bank Capital. Journal of Finance, 55, 2431-2465. https://doi.org/10.1111/0022-1082.00296

Farhi, E. and Tirole, J. (2012). Collective Moral Hazard, Maturity Mismatch and Systemic Bailouts. American Economic Review, 12(1), 60-93. https://doi.org/10.1257/aer.102.1.60

Hattori, A., Kikuchi, K., Niwa, F., and Uchida, Y. (2014). A Survey of Systemic Risk Measures: Methodology and Application to the Japanese Market. IMES Discussion Paper Series, No. 2014-E-3.

Hendricks, D., Kambhu, J., and Mosser, P. (2006). Systemic Risk and the Financial System: Background Paper. NAS-FRBNY Conference on New Directions in Understanding Systemic Risk held at Federal Reserve Bank of New York on May 18, 2006.

Jarrow, R. (2012). Capital Adequacy Rules, Catastrophic Firm Failure, and Systemic Risk. Cornell University, Johnson School Research Paper Series \#5-2012. https://doi.org/10.2139/ssrn.2084200

Laeven, L. and Levine, R. (2007). Is there a diversification discount in financial conglomerates? Journal of Financial Economics, 85, 331-367. https://doi.org/10.1016/j.jfineco.2005.06.001

Laeven, L., Ratnovski, L., and Tong, H. (2016). Bank Size, Capital, and Systemic Risk: Some International Evidence. Journal of Banking and Finance, 69(1), S25-S34. https://doi.org/10.1016/j.jbankfin.2015.06.022

Miles, D., Yang, J., and Marcheggiano, G. (2012). Optimal bank capital. The Economic Journal, 123, 1-37. https://doi.org/10.1111/j.1468-0297.2012.02521.x

Moore, K. and Zhou, C. (2014). The Determinants of Systemic Importance. Systemic Risk Centre, London School of Economics, Discussion Paper No. 19.

van Oordt, M.R.C. and Zhou, C. (2015). Systemic Risk and Bank Business Models. De Nederlandsche Bank Working Papers, Paper No. 442. https://doi.org/10.2139/ssrn.2509314 